\title{
Possible roles of arachidonic acid content for sustaining larval-pupal and pupal-adult development of the immersed larvae of the flesh fly, Boettcherisca peregrina
}

\author{
Atsuko Moribayashi, Hiromu Kurahashi and Noriaki Agui \\ Department of Medical Entomology, The National Institute of Health, \\ Toyama 1-23-1, Shinjuku-ku, Tokyo, 162 Japan
}

(Received: 24 May 1996; Accepted: 21 June 1996)

\begin{abstract}
Key words: Boettcherisca peregrina, flesh fly, immersed larvae, survival rate, lipid, arachidonic acid
\end{abstract}

\begin{abstract}
The mature larvae of the flesh fly, Boettcherisca peregrina, normally required 12 days to develop to adults at $25^{\circ} \mathrm{C}$ in dry condition. When the mature larvae were immersed in water, their development was arrested. However, their further development was resumed when they were transferred to dry condition. The rates of survival and adult emergence in the mature larvae did not change during 10 days of immersion but these rates decresed to zero by the additional immersion for another 5 days. During immersion for 14 days, the total lipid content of the immersed larvae decreased drastically from $6 \%$ to $1 \%$ of body weight, although that of the normal developing larvae placed in dry condition did not decrease markedly. One of main fatty acids in the lipid of $B$. peregrina was arachidonic acid and this fatty acid comprised of $10.5 \%$ in the total fatty acids extracted from the mature larvae. During normal adult development, absolute amount of arachidonic acid decreased to $43 \%$ of that in the normal mature larvae. This decrease was more conspicuous in larvae immersed in water. The amount decreased to $22 \%$ after 10 days and $9 \%$ after 14 days immersion, respectively. Whereas other fatty acids did not decrease so marked as arachidonic acid. These results suggest that there may be a threshold content of arachidonic acid to complete successful larval-pupal and pupal-adult development in B. peregrina.
\end{abstract}

\section{INTRODUCTION}

The larvae of flesh fly, Boettcherisca peregrina, develop in privies where they are immersed and exposed to moisture. The mature larvae cease feeding and wander from the immersed breeding site to dry environment for pupation. The wandering mature larvae transform to pupariae in one day and to pupae in another day, and then adults emerge after 10 days in the dry environment at $25^{\circ} \mathrm{C}$. Interesting$l y$, in the mature larvae of $B$. peregrina the puparium formation is blocked by contin- uous immersion in water and these larvae finally die without further development (Ohtaki, 1966). The larvae immersed in water for a certain period, however, resume normal development by transfer to dry condition and puparium formation takes place approximately $20 \mathrm{~h}$ after the dry-treatment. In order to clarify physiological effects of continuous water immersion on further development of mature larvae of $B$. peregrina, we precisely compared the rates of survival and adult emergence in the mature larvae under dry and wet condition.

Recently, Stanley-Samuelson (1994) and 
Stanley-Samuelson and Pedibhotla (1996) have reviewed that prostaglandins and other eicosanoids, which include all of the biologically active metabolites of arachidonic acid and certain other C20 polyunsaturated fatty acids, play physiologically crucial regulatory roles in insects as well as in mammals. For instance, these lipids play the roles in reproduction, homeostatic immunity, homeostatic fluid secretion by Malpighian tubules and thermoregulation in some insects (StanleySamuelson et al., 1988).

We performed qualitative and quantitative analyses of lipids and fatty acids of the immersed larvae of $B$. peregrina, and then demonstrated a relationship between the quantitative change of arachidonic acid and the survival rate of the larvae kept in the immersed condition. Together with these results we discussed the physiological significance of arachidonic acid for survival of $B$. peregrina during the larval-pupal and pupal-adult development.

\section{Materials and Methods}

Experimental insects. A colony of $B$. peregrina, $B p$ (Tokyo), maintained routinely in our laboratory was used for this experiment. Adults were reared under $16 \mathrm{~h}$ light: $8 \mathrm{~h}$ dark (16L:8D) cycle at $25^{\circ} \mathrm{C}$ and all experiments were carried out under these conditions. Larvae bred on pork liver became fully grown larvae after 4 days. The fully grown larvae were then placed in water for 2 days to synchronize their developmental stages. The immersed larvae in water purged their gut contents during 2 days and became mature larvae at wandering stage. These post-feeding, wandering mature larvae were designated as "mature larvae" in this experiment. The mature larvae that were transferred to dry condition formed the puparium 1 day later and adults emerged within 12 days.

Effect of water-immersion on survival of mature larvae and adult emergence. To observe survivorship during immersion in water, 3 groups of 100 mature larvae were immersed continuously in a small amount of distilled water and the number of surviving larvae was determined daily for 15 days. Larvae showing no movement or a darkened color were regarded as dead larvae and were eliminated from each group. Eighteen groups of 20 larvae were prepared to investigate the effect of immersion on the development to adult. Immediately after the start of experiments one group was transferred to dry sawdust as a control and the remaining groups were immersed in water as tests. From the second day, one of the immersed groups was daily transferred to dry sawdust. Water used to immersion was changed to fresh distilled water every day during the experiment. The larvae transferred to the dry sawdust were examined every day for adult emergence.

Lipid extraction. Ten larvae of each group in control and immersed were daily weighed and then homogenized with a hand-driven glass homogenizer in $50 \mathrm{ml}$ of mixture with methanol and chloroform (1: $1, \mathrm{v} / \mathrm{v})$. The homogenate was subjected to extraction by continuous agitation at room temperature for one day. The homogenates were centrifuged at $1,000 \times g$ for $10 \mathrm{~min}$ at $4^{\circ} \mathrm{C}$ and the supernatants were filtrated with filter paper (Toyo No. 2, Toyoroshi Co., Ltd., Tokyo). The filtrates were evaporated under low air pressure and the lipids were purified with chloroform, methanol and water according to the method of Bligh and Dyer (1959). The lipids in the chloroform phase were filtrated with Millipore filters (type $\mathrm{FH}$, pore size $0.5 \mu$, Millipore Co., Bedford, MA) and allowed to dryness on vacuum, and finally weighed.

Analysis of fatty acids. To identify the fatty acid composition in the isolated lipids, methylation of the fatty acids was carried out by methanolysis with $5 \%$ hydrochloric acid-methanol in a sealed tube at $110^{\circ} \mathrm{C}$ for $2 \mathrm{~h}$. Methylated fatty acids obtained from ten larvae were dissolved in a small amount of hexane and analyzed by 
gas liquid chromatography (GLC).

GLC was performed with a Shimadzu type GC 7A apparatus equipped with a hydrogen flame ionization detector. Glasscoiled columns $(0.3 \times 210 \mathrm{~cm})$ packed with $5 \%$ Advans DS or 3\% SE-30 (Applied Science Laboratories, Inc., State College, PA) on Chromosorb W (Shimadzu Scientific Instruments, Inc., Kyoto) were used. Each methylated fatty acid was identified by comparing its retention time with those of methylated standards. The peak area corresponding to each fatty acid was calculated quantitatively with a Shimadzu CR4 A Chromatopac integrator (Shimadzu Scientific Instruments, Inc., Kyoto).

Further analyses of methylated fatty acids were performed to confirm the location of unsaturated carbon chain in polyunsaturated fatty acid molecules by GLCMass spectrometry (GLC-MS). Analyses were conducted on an Hewlett-Packard (HP) HP-5890 GC-MS (Hewlett-Packard, Palo, Alto, CA.) equipped with Supelco wax 10 capillary column $(0.25 \mathrm{~mm} \times 30 \mathrm{~m})$ (Supelco, Inc., Bellefonte, PA).

Chromatographic conditions included $45 \mathrm{~s}$ splitless injection, a $1 \mathrm{~min}$ hold period and $20^{\circ} \mathrm{C} / \mathrm{min}$ temperature program from 50 to $220^{\circ} \mathrm{C}$. Ultra pure $\mathrm{He}_{2}$ was the carrier gas at $1 \mathrm{ml} / \mathrm{min}$. Retention times and total ion mass spectra of fatty acid methyl esters were compared with those of authentic standards from Sigma Chemical Co. (St. Louis, MO).

Calculation of absolute amount of fatty acids. The absolute amount (A) of each fatty acid was calculated by the numerical formula, $A=W L F$ using 3 parameters such as the body weight of the larva (W), the lipid content per body weight of each insect (L) and the ratio of each fatty acid to total lipid in each insect $(F)$. By using this formula, the absolute amounts of main fatty acids extracted from insect at each stage are calculated.

\section{RESUlts}

Effects of immersion of larvae on survival and adult emergence

Similar rates in larval survival and adult emergence were obtained by water immersion (Fig. 1). The larvae immersed in water showed high survival rates during 10 days of immersion, but the survival rate declined rapidly thereafter and no survivor was found after 15 days of immersion. Adult emergence of the immersed larvae after transfer to dry condition was relatively high until 10 days (average of $98 \%$ ), and it dropped to $50 \%$ and $0 \%$ for larvae immersed until day 12 and day 15 , respectively.

Changes in body weight and lipid content

Figure 2 shows the change in body weight of flies in either dry or immersed conditions. The mature larvae transferred to dry condition resumed normal development and emerged into adults on day 12 . During this period, the body weight decreased from 100 to $65 \mathrm{mg}$ per insect. Decrease in weight was conspicuous until

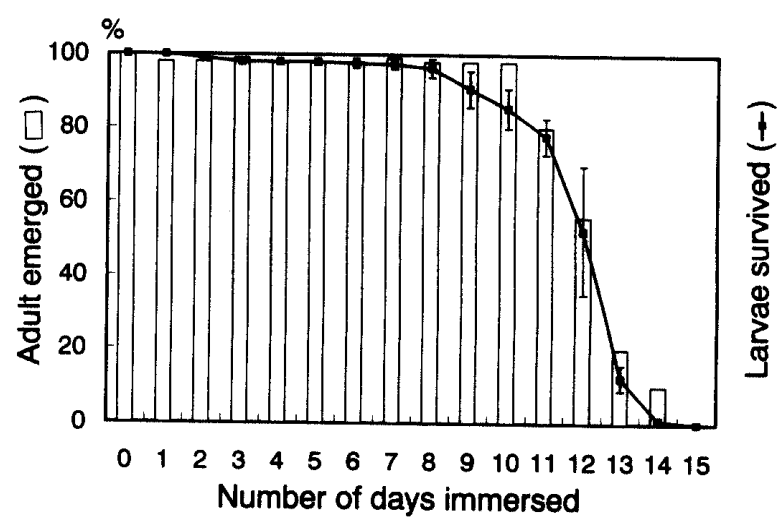

Fig. 1. Survival and adult emergence of mature larvae of $B$. peregrina immersed in water for 15 days.

Three groups of 100 mature larvae were initially used to investigate effect of water immersion on survival of mature larvae. Each point represents the mean of three determinations with SE. Fifteen groups of 20 mature larvae were used to observe effect of water immersion on adult emergence. One group per day was transferred to dry condition for further determination of adult emergence in each group. 


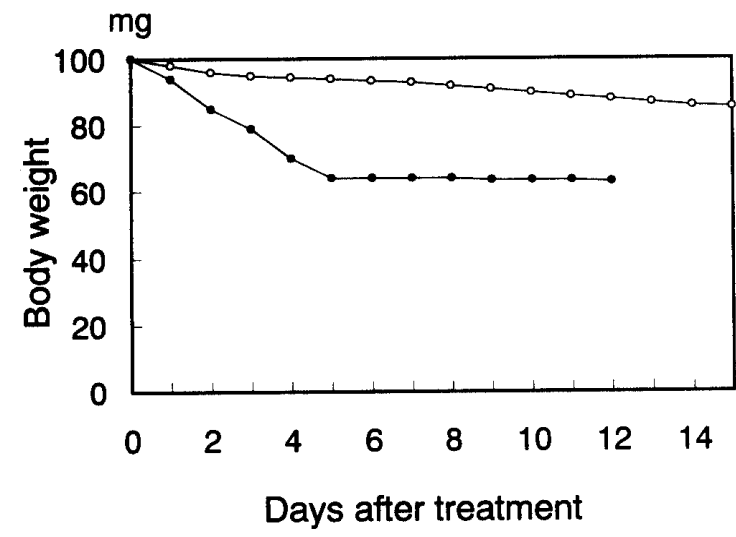

Fig. 2. Changes in body weight of mature larvae of $B$. peregrina in water immersion $(-\bigcirc-)$ and in dry condition (-O-).

One hundred of mature larvae were initially used in both treatments. Each point shows the average of body weight of surviving larvae. The weight of flesh adults on day 12 was determined by the adult weight plus pupal exuviae.

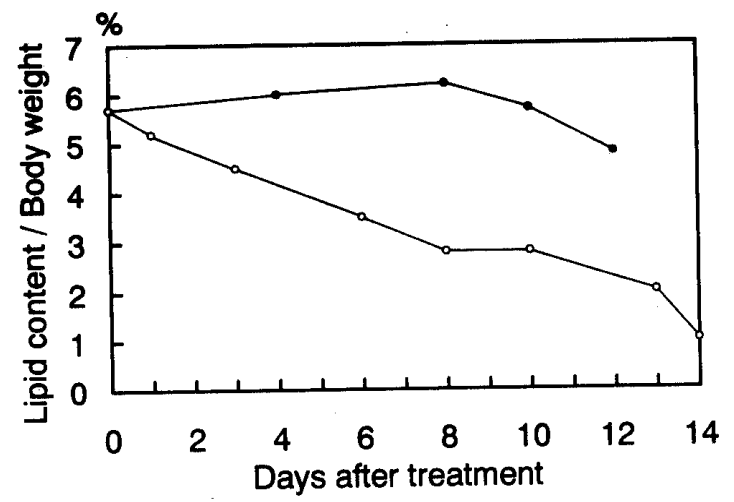

Fig. 3. Lipid content per body weight in mature larvae of $B$. peregrina in water immersion (-O-) and in dry condition (-O).

Each point shows the average of lipid content of ten test insects.

day 5 but after that it was almost unchanged. The body weight of larvae immersed in water decreased gradually from $100 \mathrm{mg}$ to $85 \mathrm{mg}$ until day 15 without any developmental progress. Thus, the change in body weight of the larvae immersed in water was less than that of the larvae transferred to the dry condition.

Figure 3 shows the rate of lipid content per body weight of larvae immersed in water or under dry condition. The rate under dry condition was initially $5.6 \%$, and then slightly decreased to $4.6 \%$ during normal adult development. Whereas,

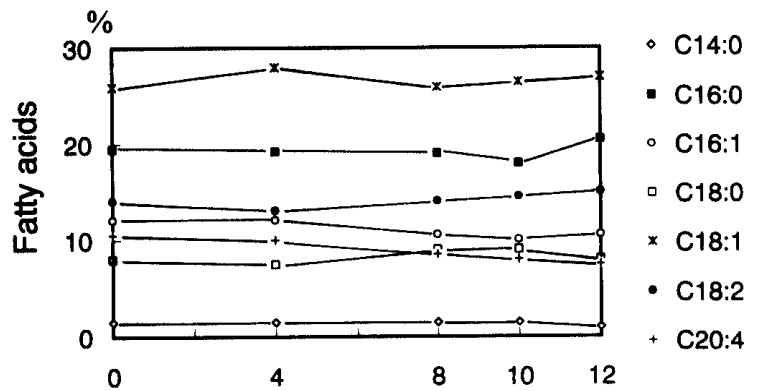

Days after transfer to dry conditions

Fig. 4-A.

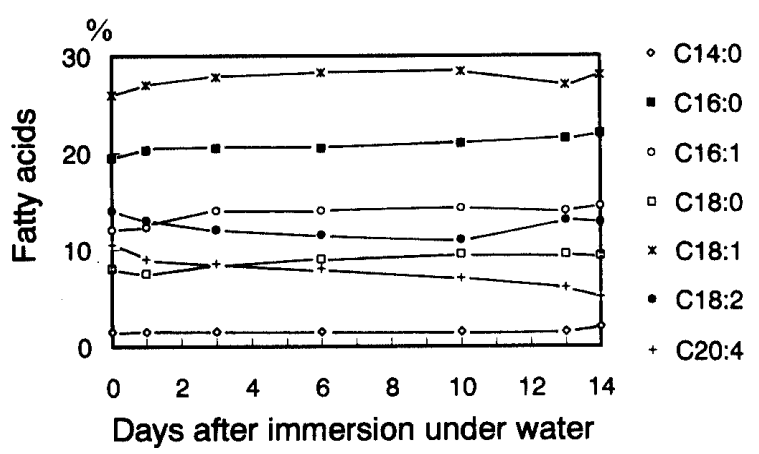

Fig. 4-B.

Fig. 4. Rates of fatty acid in lipids obtained from mature larvae of $B$. peregrina in water immersion and in dry condition.

A. Rates of fatty acids in the lipids extracted from control insects at different stages from mature larvae to freshly emerged adults. B. Rates of fatty acids obtained from mature larvae immersed in water for 14 days.

Fatty acids were analyzed by gas liquid chromatography as described in the Materials and Methods. Fatty acids determined here were as follows; myristic acid (C14:0), palmitic acid (C16:0), palmitoleic acid (C16: 1), stearic acid (C18:0), oleic acid (C18:1), linoleic acid (C18:2) and arachidonic acid (C20:4).

the rates of those immersed in water decreased drastically from $5.6 \%$ on day 0 to $1.0 \%$ on day 14 .

\section{Fatty acid levels}

The fatty acids of the lipid obtained from the larvae just before immersion were composed of both saturated and unsaturated carbon chains of which lengths are $14,16,18$ and 20 as determined by GLC and GLC-MS (Fig. 4). They were mainly oleic $(\mathrm{C} 18: 1,25.6 \%)$, palmitic (C16:0, 20.0\%), linoleic (C18:2, 14.0\%), palmitoleic (C16:1, 12.3\%), arachidonic (C20:4, 10.5\%), stearic $(\mathrm{C} 18: 0,8.4 \%)$ and 


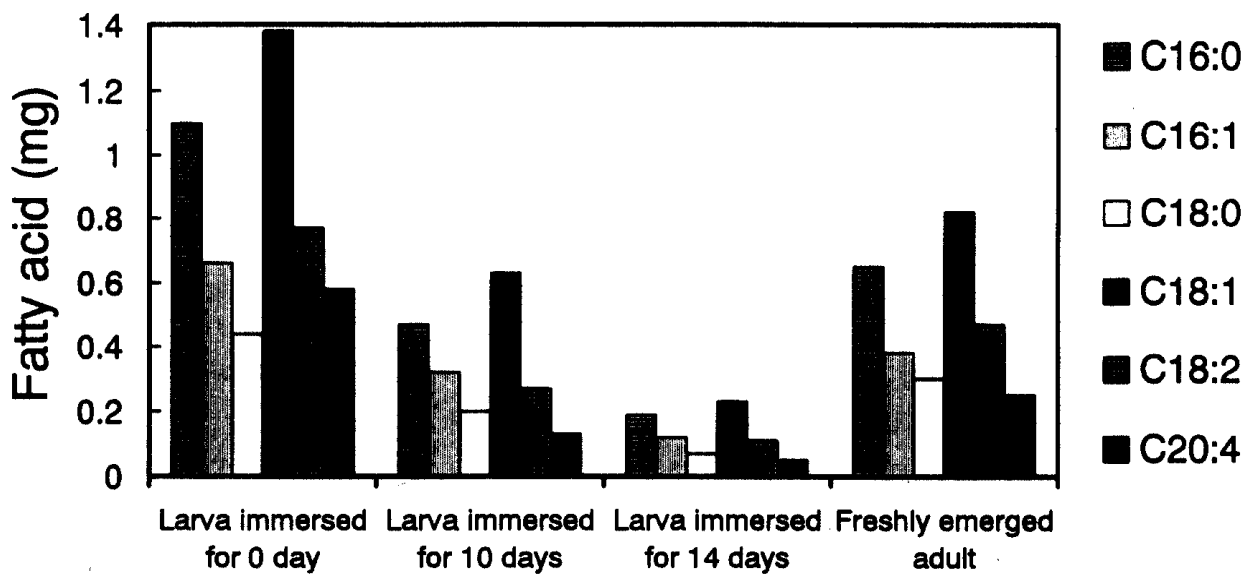

Fig. 5. Absolute amount of fatty acids in lipids extracted from $B$. peregrina freshly emerged adults and mature larvae kept in different days of water immersion.

Six fatty acids of mature larvae kept in water for 10 and 14 days, respectively, and of freshly emerged adults were represented in this figure. Detail of calculation method for fatty acid content was described in the Materials and Methods.

myristic $(\mathrm{C} 14: 0,1.4 \%)$ acids (Fig. 4-A). The rates of main fatty acids of larvae in dry condition were nearly constant throughout larval to adult development. The exception was arachidonic acid. It decreased $3 \%$ (from 10.5 to $7.5 \%$ ) during normal adult development (Fig. 4-A). However as shown in Fig. 4-B, the arachidonic acid of larvae kept in the immersed condition decreased $5.5 \%$ (from $10.5 \%$ to $5.0 \%)$ after 14 days of immersion. Thus, this decrease was more prominent than that of larvae kept in dry conditions.

Absolute amounts of arachidonic acid in the mature larvae and freshly emerged adults was $0.58 \mathrm{mg}$ and $0.25 \mathrm{mg}$, respectively. Namely, arachidonic acid decreased to $43.1 \%$ during normal adult development. Absolute amounts of arachidonic acid obtained from each larva of day 10 and day 14 in the immersed conditions were $0.13 \mathrm{mg}$ and $0.05 \mathrm{mg}$, respectively (Fig. 5). Arachidonic acid of larvae during 10 days and 14 days of immersion decreased to $22.4 \%$ and $8.6 \%$, respectively. Furthermore, decrease of arachidonic acid in the immersed larvae was more pronounced than those of other fatty acids, such as palmitic, palmitoleic, stearic, oleic and linoleic acids. In this connection, palmitic, palmitoleic, stearic, oleic and linoleic acids of day 0 mature larvae vs. those of day 14 immersed larvae decreased to almost same, i.e. $17.3 \%, 18.2 \%, 15.9 \%$, $16.7 \%$ and $14.3 \%$, respectively (Fig. 4-B).

Most larvae in the immersed condition until day 10 were able to develop to adults (Fig. 1). However, the lipid content of day 10 immersed larvae decreased to $1 / 2$ of that in dry condition (Fig. 3). The absolute amount of arachidonic acid of day $10 \mathrm{im}$ mersed larvae decreased to approximately $1 / 4$ and $1 / 2$ of that of larvae immersed for 0 day and freshlly emerged adults, respectively (Fig. 5).

Thus, a certain level of arachidonic acid in lipids may work physiologically to insure survival and continuous development of the larvae as one of important regulatory factors in $B$. peregrina, since the change of arachidonic acid was more prominent than that of other fatty acids.

\section{Discussion}

To clarify the physiological effect of water immersion on mature larvae at the post-feeding, wandering stage of $B$. peregrina, we investigated their mortality and lipid content. $B$. peregrina larvae could withstand the water immersion for 10 days without substantial mortality, but all died by the 15th day of immersion in water. While, lipid content of mature 
larvae in the immersed condition decreased more markedly than those of normally developing larvae. In general, lipids and fatty acids are very significant factors physiologically as a source of metabolic energy and structural components of cells in insects as well as in mammals (Downer, 1985; Stanley-Samuelson et al., 1988). We assume that the marked decrease of lipid content of larvae in the immersed condition may be the resultant of consumption of metabolic energy to compensate the physiologically unfavorable condition under a long-term water immersion.

Dadd (1983) suggested that many insects require the $\mathrm{C} 18$ polyenoics, linoleic and linolenic acids as their essential fatty acids. Arachidonic acid is also essential for mosquitoes and this fatty acid cannot be replaced by linoleic and linolenic acids (Dadd, 1981). Furthermore, Dadd and Kleinjan (1984) showed particular functions of arachidonic acid by the studies on effects of specific inhibitors on prostaglandin synthetase in mosquitoes: High concentration of dietary arachidonic acid enhanced overall development of larvae and viability of newly emerged adults. In the present studies, the arachidonic acid of $B$. peregrina during larval-pupal and pupal-adult development decreased more remarkable than other fatty acids. The absolute amount of arachidonic acid of freshly emerged adults was $1 / 2$ of that in the matured larvae. While, the values of day 10 and day 14 immersed larvae were approximately $1 / 4$ and $1 / 8$ compared to those of the matured larvae, respectively (Fig. 5). Rates of adult emergence under 10 and 15 days-immersion were at $85 \%$ and $0 \%$, respectively (Fig. 1). These results suggest that $B$. peregrina may require a critical content of arachidonic acid to sustain their larval-pupal and pupal-adult developments.

We measured the amounts of arachidonic acid in diapause of $B$. peregrina. The amount of arachidonic acid of mature larvae destined for diapause was $0.67 \mathrm{mg}$ per one larva. Whereas that amount was
$0.18 \mathrm{mg}$ in the adult freshly emerged after 5 months of pupal diapause (Moribayashi et al., unpublished). Thus, arachidonic acid content in the diapause pupae decreased to $26.9 \%$ at diapause termination. The amount and the decreasing rate of arachidonic acid of the newly emerged adult after termination of pupal diapause were relatively very close to those of larvae immersed for 10 days $(0.18 \mathrm{mg}$, $26.9 \%$ vs. $0.15 \mathrm{mg}, 25.9 \%$ ). Interestingly, the survival rate of the adult emerged after 5 months of pupal diapause was approximately $90 \%$ and this rate was similar to that of immersed larvae for 10 days.

The amount of oleic acid was the highest in the fatty acids. This fatty acid decreased to $16.7 \%$ (from 1.38 to $0.23 \mathrm{mg}$ ) during 14 days of immersion. Thus, the decreasing rate of oleic acid was lower than that of arachidonic acid (8.6\%). The decreasing rates of the other fatty acids except for arachidonic acid was similar to that of oleic acid. These results clearly indicated that the physiological requirement of arachidonic acid during larvalpupal and pupal-adult developments was higher than other fatty acid. It seems to be meaning relation between the amount of arachidonic acid and survival rate of immersed larvae in the water. Even if arachidonic acid decreased to levels in the twenties \% of an initial amount, $B$. peregrina pupae may be able to accomplish adult development at relatively a good efficiency. However, if arachidonic acid decreased less than to $10 \%$, the accomplishment of adult development may become very difficult. Together with the present results, it is strongly suggested that arachidonic acid is one of biologically significant factors in $B$. peregrina for development and for survival under unfavorable circumstances.

\section{ACKNOWLEDGEMENTS}

We thank Dr. Y. Tanaka, Department of Biochemistry and Cell Biology, for analysis of GC-MS, and also Dr. J. D. Wells, Department of Medical Entomology, 
The National Institute of Health, Tokyo, Japan, and Dr. K. J. Yagi, Department of Zoology, University of Toronto, Ontario, Canada for reading the manuscript. This work was supported in part by grant of the Ministry of Health and Welfare (KenkochikyuKenkyu in 1993-1995).

\section{REFERENCES}

Bligh, E. and W. J. Dyer (1959) A rapid method of total lipid extraction and purification. Can. J. Biochem. Physiol., 37: 911-917.

Dadd, R. H. (1981) Essential fatty acids for the mosquitoes, other insects and vertebrates. In: Current Topics in Insect Endocrinology and Nutrition (ed., Bhaskaran, G., S. Friedman and J. G. Rodriguez), pp. 189-214, Plenum Press, New York.

Dadd, R. H. (1983) Essential fatty acids: insects and vertebrates compared. In Metabolic Aspects of Lipid Nutrition in Insects (ed., Mittler, T. E. and R. H. Dass), pp. 107-142, Westview Press, Boulder, Colorado.

Dadd, R. H. and J. E. Kleinjan (1984) Prostaglandin synthetase inhibitors modulate the effect of essential dietary arachidonic acid in the mosquito Culex pipiens. J. Insect Physiol., 30: 721-728.

Downer, R. G. H. (1985) Lipid metabolism. In: Comprehensive Insect Physiology, Biochemistry and Pharmacology. (ed., Kerkut, G. A. and L. I. Gilbert), pp. 77-113, Pergamon Press, Oxford.

Ohtaki, T. (1966) On the delayed pupation of the flesh fly, Sarcophaga peregrina Robineau-Desvoidy. Jpn. J. Med. Sci. Biol., 19: 97-104.

Stanley-Samuelson, D. W. (1994) Assessing the significance of prostaglandins and other eicosanoids in insect physiology. J. Insect Physiol., 40: 3-11. Stanley-Samuelson, D. W., R. A. Jurenka, C. Cripps, G. J. Blomquist and M. Renobales (1988) Fatty acid in insect: composition, metabolism and biological sig. nificance. Archs. Insect Biochem. Physiol., 9: 1-33.

Stanley-Samuelson, D. W. and V. K. Pedibhotla (1996) What can we learn from prostaglandins and related eicosanoids in insects? Insect Biochem. Molec. Biol., 26: 223-234.

$$
\begin{gathered}
\text { 畝 } \\
\text { 水浸漬されたセンチニクバエ成就幼虫の蛹化 } \\
\text { および成虫化へのアラキドン酸量の役割 } \\
\text { 森 林 敦 子 倉 橋 弘 安居院宣昭 } \\
\text { 国立予防衛生研究所昆虫医科学部 } \\
\text { （テ162 東京都新宿区戸山 1-23-1） }
\end{gathered}
$$

センチニクバエの成熟幼虫は， $25^{\circ} \mathrm{C}$ の温度条件下で は 12 日後に成虫となるが, 水に浸漬するとその成虫化 は阻止され，水浸清から乾燥条件下に移すとその成虫化 は進行する. 10 日間の水浸漬では, 生存率, 羽化率共に 変化がないが, 15 日間の水浸清では, それらの率が急激 に隇少し $0 \%$ になった。一方, 水浸漬 14 日後の幼虫の 脂質量は，6\%から $1 \%$ に減少した。正常発育した成虫 では，このような著しい脂質の減少は認められなかっ た．脂質に含まれる主な構成脂肪酸の一つであるアラキ ドン酸は, 浸清前の幼虫では構成脂肪酸の $10.5 \%$ （0.58 $\mathrm{mg} / 1$ 匹) をしめているが, 水浸漬 10 日後および 14 日 後のそれは，それぞれ浸漬前の幼虫の $22 \%(0.13 \mathrm{mg})$ ， 9\% (0.05 mg) に減少した.このような顕著な減少は了 ラキドン酸以外の構成脂肪酸では認められなかった。こ れらの結果から，七ンチニクバエにおいては成熟幼虫が 蛹一成虫への分化・発育を達成するためには, ある知界 量 (闘値) のアラキドン酸の存在が重要であることが示 唆された。 